\title{
Reflective practice on lesson planning among EFL teacher educators
}

\author{
Lulu Laela Amalia ${ }^{1 *}$, Utami Widiati ${ }^{2}$, Yazid Basthomi ${ }^{2}$, and Bambang Yudi Cahyono \\ ${ }^{1}$ Department of English Education, Faculty of Language and Literature Education, \\ Universitas Pendidikan Indonesia, Jl. Dr. Setiabudhi No. 229, Bandung, West Java, Indonesia \\ ${ }^{1,2}$ Department of English, Faculty of Letters, Universitas Negeri Malang, Jl. Semarang No. 5, \\ Malang, East Java, Indonesia
}

\begin{tabular}{|c|c|}
\hline $\begin{array}{l}\text { ABSTRACT } \\
\text { As an important part of teacher professional development, } \\
\text { in the 1980s. Along with it, many scholars have researche } \\
\text { one of which is English Language Teaching. The present } \\
\text { teacher educators in a doctoral program, focusing on how } \\
\text { their lessons ranging from their earliest teaching years up } \\
\text { with a multiple case study design is employed in this study. } \\
\text { both narrative and non-narrative data, are collected by usin } \\
\text { data are then coded and analyzed using thematic analysi } \\
\text { learning from experience in lesson planning helps teacl } \\
\text { performance. }\end{array}$ & $\begin{array}{l}\text { ctive practice started to flourish } \\
\text { ective practice in various fields, } \\
\text { explores reflective practice by } \\
\text { flect on the journey of planning } \\
\text { r future hope. Narrative inquiry } \\
\text { ata in this study, which included } \\
\text { tive frames and interviews. The } \\
\text { results of the study show how } \\
\text { ucators improve their teaching }\end{array}$ \\
\hline Keywords: Lesson planning; narrative inquiry; reflective & ; teacher educators \\
\hline $\begin{array}{cc}\text { First Received: } & \text { Revised: } \\
29 \text { September } 2019 & \text { 29 November } 2019 \\
\text { Final Proof Received: } & \\
\text { 20 May 2020 } & \\
\end{array}$ & $\begin{array}{l}\text { Accepted: } \\
\text { 17 December } 2019 \\
\text { Published: } \\
\text { 31 May 2020 }\end{array}$ \\
\hline $\begin{array}{l}\text { How to cite (in APA style): } \\
\text { Amalia, L. L., Widiati, U., Basthomi, Y., \& Cahyono, B. Y } \\
\text { lesson planning among EFL teacher educators. Indor } \\
\text { 10(1), 153-160. https://doi.org/10.17509/ijal.v10i1.2 }\end{array}$ & $\begin{array}{l}\text { 0). Reflective practice on } \\
\text { ournal of Applied Linguistics, }\end{array}$ \\
\hline
\end{tabular}

\section{INTRODUCTION}

Reflective practice (RP) has commonly been acknowledged as an important part of teacher professional development. It is a fundamental feature of learning from experience (Russell, 2017). While $\mathrm{RP}$ is part of what is currently expected from teachers, there has been a concern for teachers to take responsibility for their professional learning and development (Zwozdiak-Myers, 2012). Reflecting requires directed interpretation, which makes the ability to reflect on pedagogical aspects of teaching a reflective practice (Patrick, 2017).

Teacher educators are critical to educational systems as they have a significant impact on the quality of teaching and learning in schools (Vanassche \& Kelchtermans, 2016). In this study, teacher educators are those who teach students at the doctoral level of universities focusing on English Language Education. The role of teacher educators is vital for preparing and developing future English teachers through their teaching, practicum supervision, and the collaborative research teacher educators and teachers engage in (Golombek 2015; Yuan 2017).

The literature has shown that research on RP can be classified into three categories based on the participants of the research. They are RP research among pre-service teachers (student teachers or prospective teachers), RP research among in-service teachers, and RP research among teacher educators. In the European context, Toom et al. (2015) researched student teachers' basic structure of their reflective thinking. The results show that the student teachers can reflect beyond practical issues on
* Corresponding Author

Email: luluamalia@upi.edu 
teaching. Another study was conducted by Buschor and Kamm (2015), demonstrating how student teachers can be supported in developing a reflective attitude and research-oriented stance.

In the Asian context, research on RP for preservice teachers is related to the level of reflections of EFL pre-service teachers through their teaching journal (Nurfaidah et al., 2017), the role of RP in helping student teachers develop their classroom management skills (Ragawanti, 2015), reflection concerning student teachers' identity and professional development (Kuswandono, 2014b), and descriptions of student teachers' reflective practice (Liou, 2001). In addition to these, Abou Baker El-Dib (2007) conducted research that examines prospective teachers' reflective thinking as it is exhibited in their action research during the teaching practice experience, and Kabilan (2007) reports the practice of reflecting on reflections by future English language teachers in the Malaysian context.

The second research category deals with reflection among in-service teachers. Moghaddam (2019) conducted a study dealing with teachers' perceptions of reflection. This study shows how an RP instrument was used in language teaching. Another study was conducted by Moradkhani et al. (2017), focusing on the relationship between EFL teachers' reflective practices and self-efficacy and teachers' teaching quality. The result of their study shows that reflection contributes to teachers' selfefficacy to improve their teaching. In other words, reflection or RP supports the improvement of teachers' teaching activity.

The next one is RP research among teacher educators. Lane et al. (2014) conducted a study that described the process followed by a group of primary and secondary teacher educators in Australia to develop a collective understanding of the nature and value of RP. The result of the study shows that the process of developing a framework highlights the value of collaborative coding and collegial discussion as methods for establishing a shared understanding and shared practice of reflective writing in teacher education. Another study was conducted by Kuswandono (2014a) in the Indonesian context. He involved teacher educators as university mentors of pre-service teachers in order to investigate their experiences in guiding pre-service teachers' RP, which is integrated in microteaching practice. This study revealed that RP could not be effectively implemented unless the embedded values of a collectivist culture are revisited and integrated with the values of RP.

Despite many studies on RP, the research on RP involving teacher educators, especially teacher educators at the doctoral level, has not focused on the individual process in their teaching activities throughout their professional journey. Teacher educators in this study are those who teach their subjects or courses to students at the doctoral level focusing on English Language Teaching (ELT). In the Indonesian context, these doctoral students are generally teacher educators at the undergraduate level in various universities across the country; their students are prospective English teachers or preservice English teachers. Therefore, conducting a study on teacher educators at a doctoral level is believed to provide multilayer benefits for the teacher education system in this country. It means that when teacher educators reveal RP on lesson planning, their practices will influence and benefit their students at the doctoral level, and when these doctoral students graduate they are responsible for educating the next generation of prospective teachers in their institutions (Richards et al., 2019). In doing so, they can pass the same influence and benefits onto their students, i.e., prospective English teachers. In this way, the teaching education system is built with a strong foundation. Thus, this study is aimed at exploring teacher educators' experiences in RP in their teaching activities, more specifically in their lesson planning, covering experience (reflection on action/RoA), present time experience (reflection in action/RiA), and future plan (reflection for action/RifA).

As an important stage in the teaching process, planning to teach includes, at the very least, knowledge of students and their needs, overall aim or aims for learning and a set of instructional objectives, and teachers' understanding and perceptions of the nature of language and learning (Nunan \& Lamb, 1996, cited in Liyanage \& Bartlett, 2010). It is stated that for teachers to plan their lessons is necessary, and lesson planning is an important part of teaching activities. This, in line with Fareh's (2018) notion, which emphasizes on a teacher to plan his or her lesson to help his/her students accomplished the anticipated learning outcomes. Planning in RoA in this study denotes the idea of experiencing reflecting on the lesson plans in their past, i.e., the early years of teaching at the doctoral level.

Furthermore, we tried to investigate RP among teacher educators in lesson planning of the present time of their teaching experience or RiA. In this study, the present time or RiA referred to the time when the study was conducted. Thus, in RiA, teacher educators designed their lesson plan in order to decide how to act upon the surprising, puzzling, unique, and unexpected responses they get from students (O'Mara, 2006). Therefore, the concept of 'present time' in RiA referred to two actions: actions based on the teaching evaluation in the same week of the course, and actions based on the stages which were planned beforehand a stages-based reflection. The next type of RP that we investigated was their lesson planning for the future plan (RifA). Therefore, the aims of this study are to investigate the teacher educators' experiences regarding RP in lesson planning within the period of teaching experience in the past, at present, and in the future. 


\section{METHOD}

The study employed a narrative inquiry with multiple case study design. Clandinin and Rosiek (2007) describe narrative inquiry as to the study of experience through the stories people share about their experiences.

The research was conducted at two doctoral programs of ELT of two universities, which used to be the teacher training institutions. The contexts were chosen because they are prominent teacher education institutions in the country. The doctoral program in these universities has been regarded as well-known ELT program whose graduates are of high quality and distributed throughout the country. In addition, the two universities were chosen because out of 12 teacher training institutes in Indonesia, and these two were the oldest ones.

The participants in this study were three teacher educators identified as TE. TE1 and TE2 were from university A in East Java, and TE3 was from university B in West Java. They were selected based on their expertise in their field. TE1 is a prominent teacher educator in ELT education and has been involved in an association in an ELT for many years. $\mathrm{He}$ is also involved in the National Board of Educational Standard in the country. TE2 is a prominent teacher educator in Linguistics and has been involved in many activities related to his expertise such as writing various articles in Linguistics, writing book reviews on Linguistics as well as giving introductory remarks on Linguistics works. TE3 is a prominent teacher educator in Literature. She has been involved in an association in Literature in the country for many years as well as in various Literature conferences and published her writings on Literature. Nevertheless, all of them have been teaching at an ELT doctoral level. The three participants were considered as prominent teachers because they have the following criteria: (1) they have been teaching the same course in a doctoral program for five years or more; (2) they have published articles in their field; and/or (3) they have been involved in the making a national education policy as well as in the professional organization for multiple years.

\section{Research procedures}

Employing a narrative inquiry, the research followed procedures proposed by Creswell (2012). The standpoint of the present study was the assumption that the more teaching experience one has, the more routines of teaching activities one does, and thus one becomes less reflective. With this assumption as our starting point, we decided to reveal teacher educators' experiences on RP in lesson planning covering past experience (reflection on action/RoA), present time experience (reflection in action/RiA), and future plan (reflection for action/RifA).

The participants were identified based on their teaching experience, knowledge on RP, and how they implemented the reflective practice in their professional journey (Zwozdiak-Myers, 2009). All participants agreed that their participation was entirely voluntary, and they gave their consent to the researchers to participate in the study as designed (Vanassche \& Kelchtermans, 2014).

In order to obtain preliminary data, a narrative frame (NF) was given to the three participants (TE1, TE2, and TE3). The narrative frame was adopted from Barkhuizen et al. (2014) to cover the information on the lesson planning in RiA, RoA, and RifA. The data from the narrative frame were used as a basis of restory or reconstructing the story. Later, the restorying process was also covered by information from the interviews. Following the data collection using narrative frames, interviews were conducted to confirm the information from the narrative frame as well as to obtain more information. Each interview lasted from 35 to 60 minutes. The interviews with TE1 and TE2 were conducted separately in person, while the interview with TE3 was held by phone. The interview data were audiorecorded and then transcribed.

The next step was to reconstruct the information collected from the narrative frame and interview transcript. The results of the restory were shown to all TEs in order to confirm and reconfirm whether the reconstructed stories were appropriate and accurate. After that, the data from the restory were categorized and labeled based on themes. The themes were identified on the basis of the literature review. In addition to this step, the data were coded to compare, contrast, and classify them. This is in line with a statement proposed by Murray (2009, cited in Heigham \& Crocker, 2009), which said that one advantage of having a code list was that it helps avoid having different codes for the same phenomenon.

The effort to maintain the accuracy and credibility of the narrative data was made by keeping the collaboration with the participants of the study throughout the process from the time of collecting, restroying, and reporting (Barkhuizen et al., 2014). In doing so, we maintained communication with all participants in different ways. We communicated more frequently with TE2 compared to our communication with TE1 and TE3. With the former, communication was more frequent in a way that TE2 had more information to share. With the latter, the communication was very strictly related to the primary data of the research, such as sending a consent form, narrative frame, and an interview protocol.

To build the trustworthiness of this narrative inquiry, we referred to the work of Lincoln and Guba (1985) and a current systematic list provided by Loh (2013). A thick description of the subjects, research procedures and research instruments were provided. To meet dependability and confirmability, every finding was supported by data. 


\section{FINDINGS AND DISCUSSION}

Findings on planning are in the form of the participants' reflection on action (experiences of past lesson planning activities), their reflection in action (experiences of present-day lesson planning activities), and their reflection for action (future hope of lesson planning activities).

\section{Participants' reflection on the action: Experiences of past lesson planning activities}

The three participants, TE1, TE2, and TE3, had their own experiences when they started teaching in a doctoral program. Although all of them did not explicitly say they did a reflection before they planned their lesson, in the statement they wrote in the NF, it showed similar ideas.

At the beginning of my teaching years, I did not really remember exactly what I did in planning my lesson, but it would be like these: (1) examining the course outlines of the previous semester done by the previous lecturer, (2) trying to check what could be improved, and (3) revising the course outline. (RoA/TE1-1)

In addition to this, TE2 stated:

In my experience as a graduate linguistics student of the doctorate degree program at the University of Hawaii (UH), I realized that linguistics is "dry subjects," particularly the so-called formal linguistics (e.g., linguistics in the Chomskyan school, where the language is treated in a mathematical way) (RoA/TE2-1). Knowing this, when I was assigned to teach Advanced Applied Linguistics for doctorate students, I shaped the course by giving personal touch. I make it appealing by providing vivid and jocular examples that keep the class 'awake.' (RoA/TE2-2)

Further TE3 stated:

The difference was when I started teaching the doctorate program, the materials of my teaching were mostly reading text materials while when I started teaching refugees years ago, I mostly used realias. But the stages were mostly the same (RoA/TE3-1)... because they were actually the only practical steps that I had learned, put into practice, and seen the benefit of doing and I think both my students (in doctorate degree) and me gained the benefit of doing this.(RoA/TE3-2)

It was apparent that the participants' experience in designing the lesson plans is similar. They were learning from previous experiences, either from other people's experience in the case of TE1 or their own experiences (TE2 and TE3). TE1 used a course outline which was designed by another teaching staff from the previous semester, and when he brought it to the class at the first meeting, he checked what could be improved by discussing the course outline with the doctorate students and improved the course outline accordingly. Despite his claim that he was not a reflective person, he had the intention to learn from experience, that is, another person's experience.
In the case of TE2 and TE3, they used their personal experience in planning their course outline in the following way. TE2 used his experience as a student of a doctoral program in Linguistics when planning his course outline. His personal experience made him aware that Linguistics, particularly the socalled formal linguistics (e.g., linguistics in the Chomskyan school), is a 'dry subject,' that is, a subject that mathematically treats language. Having experienced this feeling, TE2 decided to shape the course he was assigned to at his early teaching years in a doctoral program by giving personal and more appealing touch for his doctoral students. He provided examples that could keep the students awake during the teaching activities. In this case, even though he claimed that he was not a reflective person when he decided to learn from his own experience from the improvement, he was a reflective teacher educator.

In the planning stage, TE3 seemed to have the stages which are the same as those in the previous period (early teaching years at doctorate level), at present, and in the future. In her early teaching years, she designed practical steps based on her experience when she was still a novice teacher in her teaching career. She did the same planning stages when she was in her previous teaching years at a doctorate level. Thus, she had an internal factor influencing her in designing a lesson plan. She learned from her own experience.

All of them designed their lesson plan accordingly. In the early years of their teaching career at the doctoral level, they had already had experience in teaching at other levels. Therefore, when designing their lesson plan, they used their experience, either their own experience (internal factor) or other people's experience (external factor). There were two TEs (TE2 and TE3) who considered an internal factor in designing the lesson plan. One is his own experience as a student when taking a doctoral program, and the other is her own experience as a novice teacher. This is in line with Valli (1997), who states that in RoA, teacher educators look back on all critical events that occurred in the classrooms and think carefully about these events. The latter, TE1, chose other people's experience or external factor, in this case, other lecturer's lesson plan in designing the lesson plan.

\section{Participants' reflection in action: Experiences of present-day lesson planning activities}

The three participants had a different experience when they were in this time dimension, 'the present day.' The following were their story.TE1 stated:

In the current time, even though I do not really care whether what I did was a reflective practice, I think now I become more reflective (RiA/TE1-1). In planning a lesson I realize that the steps I conducted in the past (1-3), which I now called 'reflection,' are as follows (1) examining the course outlines of the previous semester done by the previous lecturer, (2) 
trying to check what could be improved, and (3) revising the course outline (RiA/TE1-2). There are several reasons as follows, the first one I feel guilty if I skip class. It does not mean that I skipped classes in the past. However, my students' reflective notes about my teaching performance are the evidence that I am useful for them even though, according to them, I am a very straightforward lecturer. So, I feel guilty every time I skip classes. (RiA/TE1-3)

\section{TE2 stated:}

In the current time, I still do not know if I become more reflective, because, in my opinion, what I have been doing is not reflective teaching. Instead, it is simply a kind of teaching that is designed in the best possible way to make the students reflect upon their academic potential, to explore within themselves germs of originality, and to develop their intellectual capacity to the fullest(RiA/TE2-1). Thus, instead of being a reflective teaching practice, my teaching performance leads students to be academically reflective (RiA/TE2-2). So, I plan my teaching by following almost the same steps as I did in the past (RiA/TE2-3). At the beginning of the second semester of the 2018-19 academic year, I added something new. Three weeks before the semester began, I contacted the Captain of the Class to divide the class into four groups. Then I assigned each group to do a pre-course assignment (RiA/TE2-4).

Meanwhile, TE3 stated:

In the current time, I might have become more reflective, but I am afraid it might not show on my planning stages (RiA/TE3-1). When I saw my students' reactions, and they are not really enthusiastic in my class, it affected me (RiA/TE3-3).

As the data above indicate, in the present time, TE1 decided to use the same steps of planning. Yet, this time, he clearly stated that what he did was a reflection. Although he designed the same steps of planning as what he did in his early years of teaching at the doctorate level, he could learn from what happened in the past teaching activity. He could improve things that needed to be improved, and he could revise the course outline when necessary based on what was happening in the class. He could change the activities in the class accordingly. What he did was in line with what O'Mara (2006) stated on how the teacher (educators) implemented RiA, that is, teachers could change the activities based on what he experienced at the moment he was in the class. In fact he learned from his past experience to improve his teaching performance. He used to learn from other people's experiences (other teaching staff) in designing the plan. In the present time, he also learned from his own experience in teaching the same subject.

In the 'present' time, TE2 stated that he followed the same steps as he did in his early teaching years in designing lesson plans. Even though he claimed that he was not yet aware whether he became more reflective, his awareness of designing the plan which was in the best possible way to make his students reflected upon their academic potential, to explore within themselves germs of originality, and to develop their intellectual capacity to the fullest, and to lead his students to be academically reflective was considered as characters of a reflective practitioner. This was in line with Farrel's statement when he was interviewed by Pang (2017, p. 3) which stated that," as reflective practitioners, teachers will be aware of their own need as teachers and their students; needs for learning and the impact of all this within their particular context." In this case, what TE2 did was a piece of evidence that he actually was a reflective practitioner. As for TE3 in her' present time', she claimed that she was more reflective even though she was worried that her being reflective was not shown in her planning stages. Because her students' reactions in her class affected her in performing her teaching, she felt that these reactions made her decide to adapt and improve the planning.

In planning, all teacher educators decided to use the same design that they chose in the previous part of their teaching experience. They have their reasons. This is because what they had planned in the past was actually effective and worked, but they make improvements in the materials or in the classroom management according to the feedback from their students and their students' reactions towards their teaching. According to Schön (1983), as stated in Finlayson (2015), reflection-in-action is a process that enables an individual to re-shape his or her thinking whilst working. Further, Calandra et al. (2009) state that reflection in action refers to 'in the moment' events. In this study, the 'in the moment' events or the present time experience covers all the teaching activities, which are planning, implementing, and evaluating during the span of time when this research was conducted. The followings are the elaborations of participants' experiences in planning their lesson in the present time.

TE1 claimed that he was not a reflective person in his early years of teaching at the doctoral level. He stated that in this 'present time' the teaching stages he did were what was called 'reflections' from what he had done earlier (in his early years of teaching at the doctoral level). It was because he learned from his past experience to improve his teaching performance. He used to learn from other people's experiences (other lecturers) in designing the plan. Now, he also learned from his own experience teaching the same subject. There was a shift from using only other people's experience to using both his own experience and other people's experience. To repeat, experiencing a shift and learning from experience (Russel, 2017) were both characters of reflective practitioners. Similar to TE1, TE2 stated explicitly that he did not do reflective teaching. He claimed that what he did was," designing the best possible way to make the students reflect upon their academic potential, to explore within themselves germs of 
originality, and to develop their intellectual capacity to the fullest." It showed that TE2 was more studentcentered than teacher-centered, that he was going to provide his doctoral students the best course and experience possible when they were taking his course.

\section{Participants' reflection for action: Future hope of lesson planning activities}

The three participants, TE1, TE2, and TE3, have different hopes for their future action. Below are their hopes.

TE1 hopes still to use the same course outline in the future. He stated:

In order to improve my teaching performance, in the future I am going to plan my lesson by doing the same steps again: (1) examining the course outlines of the previous semester done by the previous lecturer, (2) trying to check what could be improved, and (3) revising the course outline (RifA/TE1-1). Because of those, I could always have good reasons to revise my course outline from time to time (RifA/TE1-2). These steps will improve my teaching performance because I feel more confident about myself in teaching the course (RifA/TE1-3)

TE2 stated:

I think in the future, I am going to plan my lesson by doing almost the same steps as I have always been doing (RifA/TE2-1).

These will improve my teaching performance because I remember a brief saying by Muhammad Iqbal, a Pakistani poet, and philosopher: at the time you understand something you did not understand before, you cross out the border of your own ignorance. Seen from this perspective, learning seems to be developing your own potential step by step, responding to your own curiosity, until eventually, you have yourself developed to the fullest (RifA/TE2-2).

TE3 stated:

In order to improve my teaching performance, in the future, I actually do not really have the plan to change the way I teach because I believe that I am quite flexible in my teaching which means that there is always the possibility to change or adapt my teaching in the most immediate time, whenever I see fit (RifA/TE3-1).

In the three of teacher educators' future hope, however, they would like to change their plans when necessary or whenever they saw the appropriate strategies. The reasons were because it gave them more confidence (TE1), it gave them chances to develop (TE2), and it was their flexibility to adapt to the situation when necessary (TE3). The formers' (TE1 and TE2) situation was in line with Schön's (1983) statement in his book about reflective practitioners, and the latter is in line with what Mutton et al. (2011) stated in their study. They proposed that experienced teacher educators allow flexibility in their planning. Furthermore, they stated that teacher educators might promote a particular planning format in order to ensure that a range of issues has been considered in the planning of the individual lesson. It also ensures that there was appropriate regard for legislative requirements or national priorities.

\section{CONCLUSIONS}

This study has reported teacher educators' reflective practices in lesson plannings. It has demonstrated that the assumption of 'the more teaching experience one has, the more routines of teaching activities one does, and thus one becomes less reflective' was not necessarily true. In lesson planning on Reflection on Action (past time), TEs conducted planning in their past experience by learning from other lecturers' plan and their own past experiences as students at doctorate level in order to adapt their experience, learn from them, and pass onto their students in better ways. In terms of Reflection in Action (present time), even though it was usually regarded as a spontaneous reflection, the concept of reflection in action referred to two actions: actions based on the teaching evaluation in the same week of the course, and actions based on the stages which were planned beforehand a stages-based reflection. In planning, either in the previous actions or in the latter ones, TEs chose to use the same stages of planning as they did in their past experience with modifications and adaptations according to what they were facing at the present time. With regard to Reflection for Action (future hope), in planning, TEs in this study decided to use the same lesson planning steps. Despite the fact that they had almost the same steps, they continuously improved, adapted, and revised the plans according to the experiences they had throughout their career to make better changes for their teaching performance due to the following reasons: it gave the feeling of having more confidence in teaching performance, provided an opportunity to develop themselves to be better teacher educators in the process as well as providing them the freedom to be flexible.

\section{REFERENCES}

Abou Baker El-Dib, M. (2007). Levels of reflection in action research: An overview and an assessment tool. Teaching and Teacher Education, 23(1), 24-35. https://doi.org/10.1016/j.tate.2006.04.002

Barkhuizen, G., Benson, P., \& Chick, A. (2014). Narrative inquiry in language teaching and learning research. Routledge.

Buschor, C. B., \& Kamm, E. (2015). Supporting student teachers' reflective attitude and research-oriented stance. Educational Research for Policy and Practice, 14(3), 231- 
245. https://doi.org/10.1007/s10671-015-9186$\mathrm{Z}$

Calandra, B., Brantley-Dias, L., Lee, J., \& Fox, D. L. (2009). Using video editing to cultivate novice teachers' practice. Journal of Research on Technology in Education, 42(1), 73-94. https://doi.org/10.1080/15391523.2009.107825 42

Clandinin, D. J., \& Rosiek, J. (2007). Mapping a landscape of narrative inquiry: Borderland spaces and tensions. In D. J. Clandinin (Ed.), Handbook of narrative inquiry: Mapping a methodology (pp. 35-76). Sage Publications. https://doi.org/10.4135/9781452226552.n2

Creswell, J. W. (2012). Educational research: Planning, conducting and evaluating quantitative and qualitative research (4th ed.). MA Pearson

Golombek, P.R. (2015). Redrawing the boundaries of language teacher cognition: language teacher educators' emotion, cognition, and activity. The Modern Language Journal, 99(3), 470-84. https://doi.org/10.1111/modl.12236

Fareh, S. (2018). Planning and Class Management. In J.I. Liontas, T. International Association \& M. DelliCarpini (Eds.), The TESOL encyclopedia of English language teaching (pp. 1-6). John Wiley \& Sons, Inc. https://doi.org/10.1002/9781118784235.eelt02 07

Finlayson, A. (2015). Reflective practice: Has it really changed over time? Reflective Practice Journal, 16(6), 717-730. https://doi.org/10.1080/14623943.2015.109572 3

Heigham, J., \& A. Croker, R. (2009). Qualitative research in applied linguistics: A practical introduction. In J. Heigham \& R. A. Croker (Eds.) Palgrave Macmillan.

Kabilan, M.K. (2007). English language teachers reflecting on reflections: A Malaysian experience. TESOL Quarterly, 41(4), 681-705. https://doi.org/10.1002/j.15457249.2007.tb00099.x

Kuswandono, P. (2014a). University mentors' views on reflective practice in microteaching: building trust and genuine feedback. Reflective Practice Journal, 15(6), 701-717. https://doi.org/10.1080/14623943.2014.944127

Kuswandono, P. (2014b). Voices of pre-service English teachers: Reflecting motivations during practicum learning. TEFLIN Journal, 25(2), 185-202.

https://doi.org/10.15639/TEFLINJOURNAL.V 25I2/185-202

Lane, R., McMaster, H., Adnum, J., \& Cavanagh, M. (2014). Quality reflective practice in teacher education: A journey towards shared understanding. Reflective Practice, 15(4), 481494. https://doi.org/10.1080/14623943.2014.900022

Lincoln, Y.S., \& Guba, E.G. (1985). Naturalistic inquiry. Sage Publications, Inc.

Liou, H.-C. (2001). Reflective practice in a preservice teacher education program for high school English teachers in Taiwan, ROC. System, 29(2), 197-208. https://doi.org/10.1016/S0346251X(01)00011-2

Liyanage, I., \& Bartlett, B. J. (2010). From autopsy to biopsy: A metacognitive view of lesson planning and teacher trainees in ELT. Teaching and Teacher Education, 26(7), 13621371. https://doi.org/10.1016/j.tate.2010.03.006

Loh, J. (2013). Inquiry into issues of trustworthiness and quality in narrative studies: A perspective. The Qualitative Report, 18(33), 1-15. https://nsuworks.nova.edu/tqr/vol18/iss33/1/

Moghaddam, R. G. (2019). Development of an instrument to measure EFL teachers' perceptions of reflective teaching. Indonesian Journal of Applied Linguistics, 9(1), 219-230. https://doi.org/10.17509/ijal.v9i1.12826

Moradkhani, S., Raygan, A., \& Moein, M. S. (2017). Iranian EFL teachers' reflective practices and self-efficacy: exploring possible relationships. System, 65, 1-14. https://doi.org/10.1016/j.system.2016.12.011

Mutton, T., Hagger, H., \& Burn, K. (2011). Learning to plan, planning to learn: The developing expertise of beginning teachers. Teachers and Teaching: Theory and Practice, 17(4), 399-416. https://doi.org/10.1080/13540602.2011.580516

Nurfaidah, S., Lengkanawati, N. S., \& Sukyadi, D. (2017). Levels of reflection in EFL pre-service teachers' teaching journal. Indonesian Journal of Applied Linguistics, 7(1), 80-92. https://doi.org/10.17509/ijal.v7i1.6861

O'Mara, J. (2006). Capturing the ephemeral: Reflection-in-action as research. NJ Drama Australia Journal, 30(2). 41-50. https://doi.org/10.1080/14452294.2006.116494 98

Pang, A. (2017). Reflective teaching and practice: Interview with Thomas Farrel. RELC Journal, 48(2), 174-179. https://doi.org/10.1177/0033688217707632

Patrick, P.G. (2017). Informal science educators and the nine dimensions of reflective practice. In Patrick (eds) Preparing informal Science educators: Perspective from science communication and education. Springer.

Ragawanti, D. T. (2015). Cultivating pre-service teachers' classroom management skills through teaching practicum: A reflective practice. TEFLIN Journal, 25(1), 117-128. https://doi.org/10.15639/teflinjournal.v26i1/11 7-128 
Richards, K., Andrew, R., \& Sinelnikov, O.A., (2019). An interdivision mentoring program: Doctoral students as mentors for pre-service teachers. Physical Educator Journal, 76 (1), 156-181. https://doi.org/10.18666/tpe-2019v76-i1-8726

Russell, T. (2017). A teacher educator's lessons learned from reflective practice. European Journal of Teacher Education, 41(1), 4-14. https://doi.org/10.1080/02619768.2017.139585 2

Schön, D.A. (1983). The reflective practitioner: How professionals think in action. Basic Books, Inc.

Toom, A., Husu, J., \& Patrikainen, S. (2015). Student teachers' patterns of reflection in the context of teaching practice. European Journal of Teacher Education, 38(3), 320-340. https://doi.org/10.1080/02619768.2014.943731

Valli, L. (1997). Listening to other voices: A description of teacher reflection in the United States. Peabody Journal of Education, 72(1), 67-88. https://doi.org/10.1207/s15327930pje7201

Vanassche, E., \& Kelchtermans, G. (2014). Teacher educators' professionalism in practice:

Positioning theory and personal interpretative framework. Teaching and Teacher Education, 44, 117-127. https://doi.org/10.1016/j.tate.2014.08.006

Vanassche, E., \& Kelchtermans, G. (2016). A narrative analysis of a teacher educator's professional learning journey. European Journal of Teacher Education, 39(3), 355-367. https://doi.org/10.1080/02619768.2016.118712 7

Yuan, R. (2017). Exploring university-based teacher educators teaching beliefs and practice: A Hong Kong study. Teaching in Higher Education, 22(3), 259-273. https://doi.org/10.1080/13562517.2016.124839 3

Zwozdiak-Myers, P. (2009). An analysis of the concept reflective practice and an investigation into the development of student teachers' reflective practice within the context of action research. Reflective Practice [Unpublished doctoral thesis]. Brunei University.

Zwozdiak-Myers, P. (2012). The teacher's reflective practice handbook: Becoming an extended professional through capturing evidenceinformed practice. Routledge 